\title{
Proteolytic cleavage of the A subunit is essential for maximal cytotoxicity of Escherichia coli 0157:H7 Shiga-like toxin-1
}

\author{
Nicholas Lea, $\uparrow$ J. Michael Lord and Lynne M. Roberts \\ Author for correspondence: J. Michael Lord. Tel: +44 1203 523598. Fax: +44 1203523701 \\ e-mail:ml@dna.bio.warwick.ac.uk
}

Department of Biological Sciences, University of Warwick, Coventry

CV4 7AL, UK

\begin{abstract}
Members of the bacterial Shiga toxin family consist of a single A subunit that is non-covalently associated with a pentamer of $B$ subunits. These toxins bind to receptors on susceptible mammalian cells and enter the cells by endocytic uptake. During cell entry, the 32 kDa $A$ subunit is cleaved by the membraneanchored protease furin to generate a catalytically active, $27.5 \mathrm{kDa} \mathrm{A}_{1}$ fragment and a $4.5 \mathrm{kDa} A_{2}$ fragment. Previous studies have shown that mutating the furin site to prevent cleavage did not significantly affect toxin potency, suggesting that cleavage is not required for toxin activity. Here it is confirmed that preventing cleavage at the usual processing site does not prevent proteolytic processing of the Escherichia coli Shiga-like toxin-1 A subunit. However, simultaneous mutation of both the primary furinrecognition site and a nearby putative furin cleavage site did prevent intracellular processing of the $A$ subunit. Comparison of the cytotoxicities of purified recombinant toxins to cultured mammalian cells demonstrated that even on prolonged incubation with toxin, the unprocessed mutant was 60 -fold less toxic than the wild-type protein or other mutants still capable of being proteolytically processed during cell entry.
\end{abstract}

Keywords: Shiga-like toxin-1, proteolytic processing, toxin A subunit, toxin activation

\section{INTRODUCTION}

The Shiga toxin family includes Shiga toxin itself (ST, from Shigella dysenteriae) and Shiga-like toxins-1 and -2 (SLT-1 and SLT-2, from enterohaemorrhagic Escherichia coli) (Tesh \& O'Brien, 1991). All of these toxins consist of an enzymic $32 \mathrm{kDa} A$ subunit, which is an RNA $N$-glycosidase that removes a specific adenine residue from $28 \mathrm{~S}$ rRNA (Endo et al., 1988), noncovalently associated with a pentamer of $7 \cdot 7 \mathrm{kDa} \mathrm{B}$ subunits, which bind the toxin to plasma-membrane globotriosyl ceramides present on susceptible mammalian cells (Lindberg et al., 1987). The toxin A subunits contain two cysteines joined by a disulphide bond. The loop between the disulphide-linked cysteines contains the sequence Arg-X-X-Arg, which is readily cleaved in vitro by trypsin (Olsnes et al., 1981) and, following toxin entry into mammalian cells, by the ubiquitous protease furin (Garred et al., 1995a). Cleavage splits the A subunit

†Present address: Haematology Laboratory, King's College Hospital, Bessemer Road, London SE5 9RS, UK.

Abbreviations: SLT, Shiga-like toxin; ST, Shiga toxin. into a $27.5 \mathrm{kDa} \mathrm{A}_{1}$ fragment, which has the RNA $\mathrm{N}$ glycosidase activity, and a $4.5 \mathrm{kDa} \mathrm{A} \mathrm{A}_{2}$ fragment. Several other bacterial toxins, including diphtheria toxin and Pseudomonas exotoxin A, must undergo an equivalent cleavage by furin during cell entry (Gordon \& Leppla, 1994) before the catalytically active polypeptide fragment can be translocated into the cytosol, where the rRNA substrates are located.

It has been reported that proteolytic cleavage increases the enzymic activity of ST between 10- (Olsnes et al., 1981) and 40-fold (Brown et al., 1980), but proteolytic nicking of SLT-1 in vitro did not increase its toxicity to mammalian cells (Kongmuang et al., 1988). It has also been shown that preventing cleavage at the furinsensitive site, using site-directed mutagenesis to remove the Arg-X-X-Arg target sequence, has no significant effect on the toxicity of ST (Garred et al., 1995b), SLT1 (Burgess \& Roberts, 1993) or SLT-2 (Samuel \& Gordon, 1994) to mammalian cells after prolonged incubation times. However, the ST study (Garred et al., 1995 b) also found that cells were able to cleave both wild-type toxin and the mutants, although the cellular locations of these cleavage steps appeared to differ. 
Apparently, ST can be cleaved at an alternative site close to the primary cleavage site for furin (Garred et al., 1995b). On the basis of this observation, it seems possible that mutant SLTs might also undergo proteolytic cleavage at a second distinct site, and the conclusion that proteolytic processing is not essential for cytotoxicity (Garred et al., 1995b; Burgess \& Roberts, 1993; Samuel \& Gordon, 1994) might not be valid. In order to test this, we have produced a recombinant SLT-1 mutant that does not undergo any apparent proteolytic cleavage during cell entry. Although this mutant retains some potency after prolonged incubation with cells, it is significantly less toxic than either wild-type toxin or the furin-site mutant, indicating that proteolytic processing to release a catalytically active fragment is required for optimal cytotoxicity.

\section{METHODS}

Bacterial strain, bacteriophage and plasmids. E. coli JM105 [supE endA sbcB15 hsdR4 rps thi $\Delta$ (lac-proAB) $\mathrm{F}^{\prime}$ (traD36 pro $A B^{+}$lacl $^{q}$ lac Z $\left.\left.\triangle \mathrm{M} 15\right)\right]$ was used for all genetic manipulations and the expression of recombinant proteins. M13mp18 was used for the production of single-stranded DNA for sequencing and site-directed mutagenesis. The coding region of SLT-1, including the Shine-Dalgarno sequence, was amplified by PCR from E. coli O157:H7 cell paste using oligonucleotide primers designed to incorporate a PstI site at the $5^{\prime}$ end and an EcoRI site at the $3^{\prime}$ end. The DNA oligonucleotides used were 5' GCTAGAATTCTCAACGAAAAATAACTT 3' and $5^{\prime}$ CGGAACTGCAGCAAGGAGTATTGTGTAATAT $3^{\prime}$. The resulting fragment was cloned into the Pst I/EcoRI sites of M13mp18. After mutagenesis, PstI-EcoRI fragments encoding the entire wild-type SLT-1 operon or mutant A subunit containing the appropriate amino acid substitutions were cloned into the PstI/EcoRI site of pUC19 to create the expression plasmids pSLTwt, pSLT1, pSLT2, pSLT3 and pSLT4. Amino acid substitutions in the various mutants are shown in Table 1.

Site-directed mutagenesis. The T7-Gen in vitro mutagenesis system (United States Biochemical) was used for the preparation of mutated M13 DNA. Mutagenic oligonucleotides,

Table 1. SLT-1 expression plasmids

\begin{tabular}{|c|c|c|}
\hline Plasmid & Mutations introduced & $\begin{array}{l}\text { Protein } \\
\text { product }\end{array}$ \\
\hline pSLTwt & None & SLT-1 \\
\hline pSLT1 & $\operatorname{Arg}_{248} \rightarrow$ Gly $/ \operatorname{Arg}_{251} \rightarrow$ Gly & SLTP1 \\
\hline pSLT2 & $\begin{array}{l}\mathrm{Ala}_{246} \rightarrow \mathrm{Gly} / \mathrm{Ser}_{247} \rightarrow \mathrm{Ala} \\
\mathrm{Ala}_{253} \rightarrow \mathrm{Gly} / \mathrm{Ser}_{254} \rightarrow \mathrm{Ala}\end{array}$ & SLTP2 \\
\hline pSLT3 & $\begin{array}{l}\operatorname{Arg}_{248} \rightarrow \text { Gly } / \operatorname{Arg}_{251} \rightarrow \text { Gly } \\
\text { Ala }_{246} \rightarrow \text { Gly } / \operatorname{Ser}_{247} \rightarrow \text { Ala } \\
\text { Ala }_{253} \rightarrow \text { Gly } / \operatorname{Ser}_{254} \rightarrow \text { Ala }\end{array}$ & SLTP3 \\
\hline pSLT4 & $\begin{array}{l}\operatorname{Arg}_{248} \rightarrow \text { Gly } / \operatorname{Arg}_{251} \rightarrow \text { Gly } \\
\text { Ala }_{246} \rightarrow \text { Gly } / \operatorname{Ser}_{247} \rightarrow \text { Ala } \\
\text { Ala }_{253} \rightarrow \text { Gly } / \operatorname{Ser}_{254} \rightarrow \text { Ala } \\
\operatorname{Arg}_{220} \rightarrow \text { Gly } / \operatorname{Arg}_{223} \rightarrow \text { Gly }\end{array}$ & SLTP4 \\
\hline
\end{tabular}

which were synthesized on an Applied Biosystems DNA synthesizer, were designed to introduce the desired changes into the coding region of SLT-1 A subunit. Mutations were confirmed by sequencing using the dideoxy chain-termination method. The oligonucleotides used were: $5^{\prime}{ }^{1130} \mathrm{CATGCA}$ TCGGCAGTTGCCGGAATGGCA ${ }^{1156} 3^{\prime}$ to generate mutant SLTP1, 5' ${ }^{1125}$ ATCATCATGGAGCGCGA ${ }^{1144} 3^{\prime}$ and $5^{\prime}$ ${ }^{1147} \mathrm{CAGAATGGGAGCTGATGAGT}{ }^{\overline{1166}} 3^{\prime}$ to generate mutant SLTP2, $5^{\prime}{ }^{1131}$ ATGGAGCGGCAGTTGCCGGAATGGGA ${ }^{1156} 3^{\prime}$ to generate mutant SLTP3, and $5^{\prime}{ }^{1046} \mathrm{GAC}$ TCTGTTGGTGTAGGAGGAATTTCTT ${ }^{\mathbf{1 0 7 3}} 3^{\prime}$ to generate mutant SLTP4. Mismatched bases are underlined and the numbering denotes the position at which the primer anneals in the sequence published by Calderwood et al. (1987).

Purification of recombinant toxin. SLT-1 was prepared from periplasmic extracts of E. coli. JM105 transformed with the wild-type expression plasmid pSLTwt or one of the mutantencoding plasmids described above. Cells were grown in Luria broth supplemented with $100 \mu \mathrm{g}$ ampicillin $\mathrm{ml}^{-1}$ to an $\mathrm{OD}_{600}$ of 0.6 (measured with a Shimadzu UV-160 spectrophotometer). Expression was induced by the addition of IPTG ( $1 \mathrm{mM}$ final concentration) and allowed to proceed for $3 \mathrm{~h}$. Cells were harvested by centrifugation $(10 \mathrm{~min}$ at $7500 \mathrm{~g}$ ), washed in $600 \mathrm{mM}$ sucrose, $300 \mathrm{mM}$ Tris/ $\mathrm{HCl}$ (pH 8.0), $1 \mathrm{mM}$ EDTA and $0.5 \mathrm{mM} \mathrm{MgCl}$, and resuspended in $1 \mathrm{mM}$ Tris/ $\mathrm{HCl}, \mathrm{pH} 7 \cdot 5$. After incubation on ice for $10 \mathrm{~min}$, cell debris was removed by centrifugation $(15 \mathrm{~min}$ at $15000 \mathrm{~g})$. The supernatant was filter-sterilized by passage through a $0 \cdot 2 \mu \mathrm{m}$ filter and applied to a $6 \mathrm{ml}$ globotriose-Sepharose affinity column (Muller et al., 1998) equilibrated with $0.5 \mathrm{M}$ $\mathrm{NaCl}$ in phosphate-buffered saline (PBS; $137 \mathrm{mM} \mathrm{NaCl}$, $2.7 \mathrm{mM} \mathrm{KCl}, 10 \mathrm{mM} \mathrm{Na}{ }_{2} \mathrm{HPO}_{4}, 1.8 \mathrm{mM} \mathrm{KH}_{2} \mathrm{PO}_{4}, \mathrm{pH} \mathrm{7.4)}$ ). The column was washed with 40 vols $0.5 \mathrm{M} \mathrm{NaCl}$ in PBS prior to eluting SLT-1 with $6 \mathrm{M}$ guanidine. $\mathrm{HCl}$. Fractions of $1 \mathrm{ml}$ were collected and immediately dialysed against PBS to remove the denaturant.

Quantification and activity of recombinant proteins. Purified recombinant toxins were quantified from their $A_{280}$ value; an absorption coefficient of 0.984 was calculated for SLT-1 from its primary sequence. Quantification was confirmed by comparison of known amounts of pure SLT-1 on silver-stained polyacrylamide gels. The activity of the recombinant proteins was determined by assessing their specific ability to depurinate 28S RNA of ribosomes isolated from untreated rabbit reticulocyte lysates (Promega). Toxins were incubated for $30 \mathrm{~min}$ at $30^{\circ} \mathrm{C}$ with $30 \mu \mathrm{g}$ purified ribosomes in a reaction volume of $30 \mu \mathrm{l}$. rRNA was isolated and the extent of depurination was determined by using the aniline assay as described previously (May et al., 1989).

In vivo proteolytic cleavage of toxins. Recombinant SLT-1 and the SLT-1 mutants were labelled with ${ }^{125} \mathrm{I}$ by the Iodogen method to a specific activity of approximately 25000 c.p.m. $\mathrm{ng}^{-1}$. Vero (African green monkey kidney) cells were grown in six-well plates in Dulbecco's modification of Eagle's medium (DMEM; Gibco-BRL) containing 5\% foetal calf serum and $2 \mathrm{mM}$ glutamine, to a density of approximately $5 \times 10^{5}$ cells per well. After washing with PBS, $100 \mathrm{ng}{ }^{125}$ I-labelled toxin $\mathrm{ml}^{-1}$ was added to each well in $1.5 \mathrm{ml}$ DMEM and the cells were incubated for various time periods. Following incubation, the cells were washed three times with PBS and lysed in cell-lysis buffer supplemented with protease inhibitors $\langle 1 \%$ Triton X-100, $150 \mathrm{mM} \mathrm{NaCl}, 50 \mathrm{mM}$ Tris/HCl, $\mathrm{pH} 7 \cdot 4$, $210 \mu \mathrm{M}$ leupeptin, $80 \mu \mathrm{M}$ chymostatin, $6 \mu \mathrm{M}$ elastinol, $1.6 \mu \mathrm{M}$ pepstatin, $0.3 \mu \mathrm{M}$ aprotinin, $1 \mathrm{mM}$ PMSF and $1 \mathrm{mM}$ EDTA). Cell debris was removed by centrifugation $(5 \mathrm{~min}$ at $7500 \mathrm{~g}$ 
and $4{ }^{\circ} \mathrm{C}$ ) and protein was precipitated from the supernatant with acetone. The resulting protein was pelleted, dried and resuspended in SDS-PAGE loading buffer and electrophoresed on $15 \%$ gels.

Cytotoxicity determination. Vero cells, grown in DMEM containing $5 \%$ foetal calf serum and $2 \mathrm{mM}$ glutamine, were plated out in 96-well plates at a density of approximately $2 \times 10^{4}$ cells per well. After removing the medium and washing with PBS, one of a range of toxin concentrations in $100 \mu \mathrm{l}$ fresh medium was added to each well and the cells were incubated at $37^{\circ} \mathrm{C}$ for the desired time. The cells were then washed with PBS, $1 \mu \mathrm{Ci}\left(3.7 \times 10^{3} \mathrm{~Bq}\right)\left[{ }^{35} \mathrm{~S}\right]$ methionine in $100 \mu \mathrm{l}$ PBS was added per well, and the plates were incubated at $37^{\circ} \mathrm{C}$ for 30 min. Labelled protein was precipitated by three washes with ice-cold $5 \%$ trichloroacetic acid and, after a further wash with PBS, solubilized in $0 \cdot 1 \mathrm{M} \mathrm{NaOH}$. The radioactivity incorporated into protein was determined by liquid scintillation counting. Each toxin concentration was assayed in quadruplicate.

SDSPAGE. Electrophoresis of proteins in the presence of SDS was carried out according to the method of Laemmli (1970). ${ }^{12.5} \mathrm{I}$-labelled toxin was visualized by fixing the gels in $10 \%$ acetic acid $/ 40 \%$ methanol followed by treatment with Amplify (Amersham) for $15 \mathrm{~min}$. Preflashed Fuji X-ray film was exposed to dried gels at $-70{ }^{\circ} \mathrm{C}$.

\section{RESULTS}

\section{Construction and expression of mutant toxins}

The SLT-1 mutants generated during this study are listed in Table 1. In mutant SLTP1, $\operatorname{Arg}_{248}$ and $\operatorname{Arg}_{251}$ of the furin target site were each changed to Gly. An earlier report suggested that, based on Edman degradation, SLT-1 A subunit was nicked between $\mathrm{Ala}_{253}$ and $\mathrm{Ser}_{254}$, present in the disulphide loop, to generate the $A_{1}$ and $A_{2}$ fragments (Takao et al., 1988). Accordingly, this Ala-Ser pair and a second pair also present in the disulphide loop, $\mathrm{Ala}_{246}$ and $\mathrm{Ser}_{247}$, were changed to Gly and Ala, respectively, to generate mutant SLTP2. Mutant SLTP3 contained a combination of the mutations present in SLTP1 and SLTP2. SLT-1 contains a second putative furin cleavage site $\left(\mathrm{Arg}_{220}-\mathrm{Val}-\mathrm{Gly}-\mathrm{Arg}_{223}\right)$ outside the disulphide loop. Thus $\mathrm{Arg}_{220}$ and $\mathrm{Arg}_{223}$ were both changed to Gly in the background of mutant SLTP3 to generate mutant SLTP4.

Recombinant wild-type SLT-1 and the four mutants listed in Table 1 were expressed in $E$. coli and purified to homogeneity by affinity chromatography on a column of immobilized synthetic globotriose (Muller et al., 1998). Fig. 1 shows the results of a typical purification.

\section{Biological activity of recombinant toxins}

The recombinant proteins were catalytically active. The $N$-glycosidase activity removes a specific adenine residue from a highly conserved loop close to the $3^{\prime}$ end of $28 \mathrm{~S}$ rRNA. Depurination renders isolated rRNA susceptible to amine-catalysed hydrolysis of the phosphodiester bonds on either side of the modification site. This cleavage generates a small RNA fragment of $\sim 390$

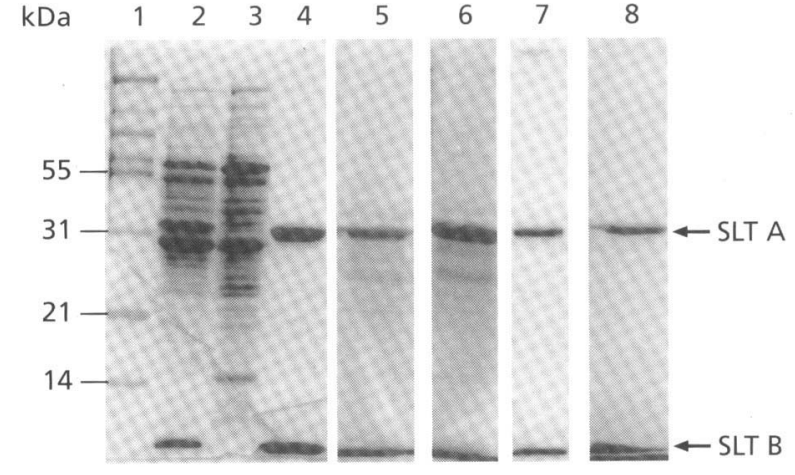

Fig. 1. Purification of recombinant SLT-1 and SLT-1 mutants. $E$. coli periplasmic fraction was passed down an immobilized globotriose column, unbound material was removed by washing and bound toxin was eluted with $6 \mathrm{M}$ guanidine. $\mathrm{HCl}$. Proteins in the various fractions were separated on a $15 \%$ SDSpolyacrylamide gel and stained with Coomassie blue. Lanes: 1 , molecular mass markers; 2 , total periplasmic fraction from cells expressing wild-type SLT-1; 3, fraction of the periplasmic fraction that did not bind to the column; 4, purified wild-type SLT-1; 5, SLTP1; 6, SLTP2; 7, SLTP3; 8, SLTP4.

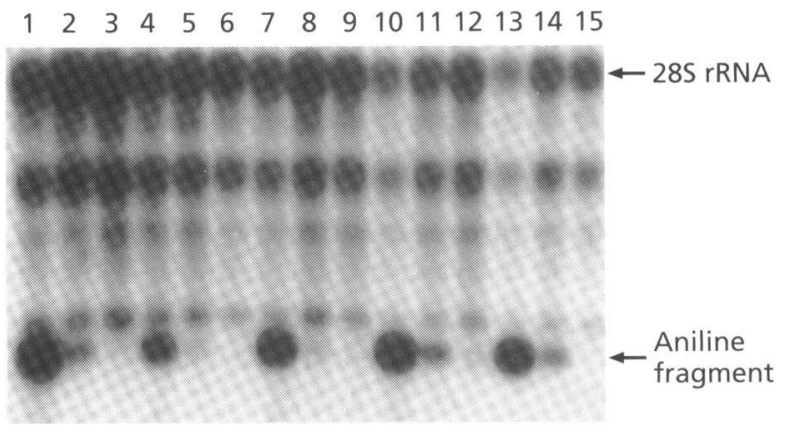

Fig. 2. $28 \mathrm{~S}$ rRNA $\mathrm{N}$-glycosidase activity of recombinant toxins. Rabbit reticulocyte ribosomes were incubated with toxin for 30 min at $30{ }^{\circ} \mathrm{C}$. rRNA was isolated, treated with aniline, separated on a $1.2 \%$ denaturing formamide gel and transferred to nitrocellulose. Northern blot analysis was performed using an end-labelled oligonucleotide probe complementary to a region of $28 \mathrm{~S}$ rRNA downstream of the depurination site. The bottom arrow (aniline fragment) indicates the $\sim 400$ base RNA fragment diagnostic for depurination. Lanes: 1-3, RNA from ribosomes treated with 1000,100 or $10 \mathrm{ng}$ wild-type SLT- $;$; 4 , 7-9, 10-12 and 13-15, RNA from ribosomes treated with the corresponding amounts of SLTP1, SLTP2, SLTP3 and SLTP4, respectively.

ribonucleotides from $28 \mathrm{~S}$ rRNA that is diagnostic of SLT-1 N-glycosidase activity. Rabbit reticulocyte ribosomes were incubated with different amounts of the purified toxins and the rRNA was isolated and treated with acetic-aniline to hydrolyse depurinated rRNA before being separated on denaturing formamide gels. The presence of the short, diagnostic RNA fragment on gels of total rRNA from toxin-treated ribosomes was confirmed by Northern blotting using a radiolabelled DNA probe complementary to a sequence present in the released RNA fragment. As shown in Fig. 2, increasing the toxin concentration caused an increased release of 

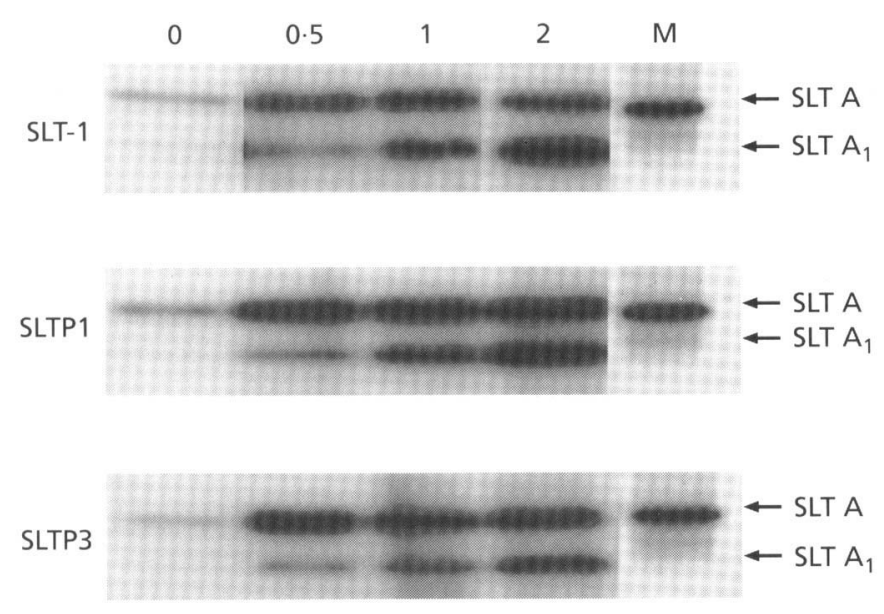

Fig. 3. In vivo proteolytic processing of recombinant toxins. ${ }^{125}$ I-labelled wild-type SLT-1 or the mutants indicated, at a

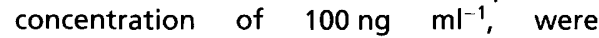
incubated with Vero cells at $37^{\circ} \mathrm{C}$ for $0,0.5$, 1,2 or $6 \mathrm{~h}$ as shown. The cells were then lysed and centrifuged to remove cell debris and total protein was precipitated with acetone. Proteins were separated on $15 \%$ SDS-polyacrylamide gels and ${ }^{125}$ I-labelled toxin was visualized by fluorography. The $A$ fragment and the $A_{1}$ fragment resulting from proteolytic cleavage are indicated. Lane $\mathrm{M}$ : a ${ }^{14} \mathrm{C}$-labelled, $31 \mathrm{kDa}$ molecular mass marker.

the fragment with a concomitant decrease in the signal for unmodified $28 \mathrm{~S}$ rRNA. Qualitatively, at least, the proteins appeared to be very similar in their abilities to depurinate rRNA. Subsequent work showed that the stability and properties of mutant SLTP2 were indistinguishable from those of wild-type SLT-1. SLTP2 was therefore not analysed further in the present study.

\section{Proteolytic processing following entry into mammalian cells}

In order to determine whether the various toxin mutants were proteolytically cleaved intracellularly, the purified toxins were labelled with ${ }^{125} \mathrm{I}$ and incubated with SLTreceptor-bearing Vero cells. After various incubation times, the cells were washed to remove extracellular toxin and lysed, total protein was precipitated and separated electrophoretically and toxin was visualized by fluorography. As shown in Fig. 3, wild-type SLT-1 and mutants SLTP1 and SLTP3 were all processed to generate the $A_{1}$ fragment, but mutant SLTP4 was apparently resistant to cellular proteolysis. The extent of cleavage of the $A$ subunit to the $A_{1}$ fragment was quantified by scanning densitometry and is shown in Fig. 4. The resistance of mutant SLTP4 to proteolytic cleavage indicates that the cleavage seen here for mutants SLTP1 and SLTP3, and that reported elsewhere for a mutant in which the furin site in the disulphide loop had been disrupted (Garred et al., 1995b), most likely occurs at the second putative furin site, $\operatorname{Arg}_{220^{-}}$ Val-Gly-Arg ${ }_{223}$.

\section{Cytotoxicity to mammalian cells}

The cytotoxicities of the wild-type and mutant SLTs were determined by measuring the capacity of Vero cells to synthesize protein after a $6 \mathrm{~h}$ incubation with a range

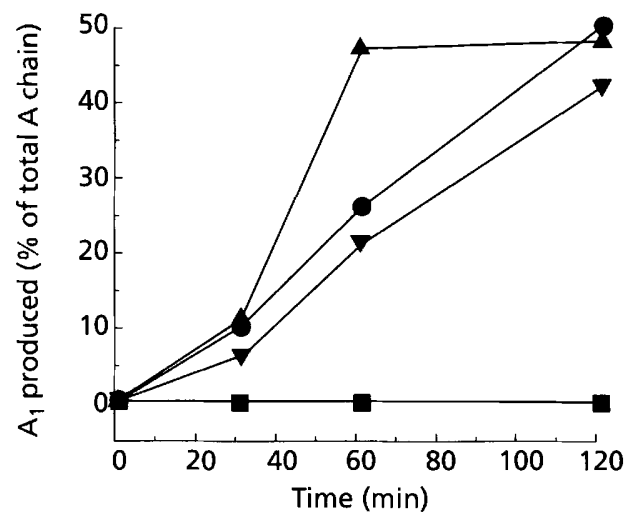

Fig. 4. Quantification of in vivo proteolytic processing. The bands shown in Fig. 3 were quantified by scanning densitometry and the proportion of total $A$ subunit present as the $A_{1}$ fragment was plotted against length of incubation. $A$ SLT-1; 0. SLTP1; $\nabla$, SLTP3; $\square$, SLTP4.

of concentrations of toxin (Fig. 5). Wild-type toxin and the mutants that could be cleaved proteolytically intracellularly were of comparable cytotoxicity, while mutant SLTP4 was clearly less toxic. The $\mathrm{IC}_{50}$ (the toxin concentration that caused a $50 \%$ decrease in total protein synthesis in comparison with that of untreated control cells) for SLTP4 was $360 \mathrm{pg} \mathrm{ml}^{-1}$, around 60 -fold greater than that for wild-type SLT-1. When cells were incubated with toxin for $3 \mathrm{~h}$, wild-type SLT appeared to be more toxic than mutants SLTP1 and SLTP3 (data not shown), indicating presumably that cleavage at the alternative site was less efficient than cleavage at the normal furin site. Incubating the cells with toxins for periods greater than $6 \mathrm{~h}$ gave toxicity profiles identical to those observed after $6 \mathrm{~h}$ (Fig. 5). The reason(s) for the 


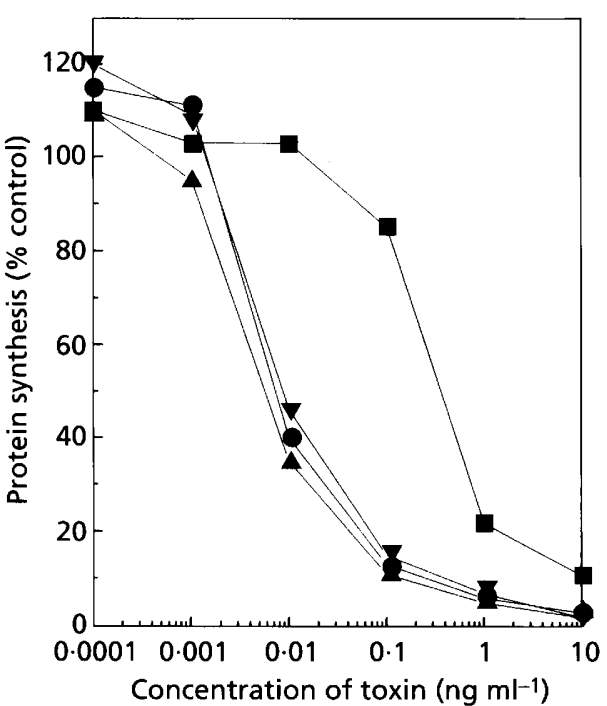

Fig. 5. Cytotoxicity of recombinant toxins. Various concentrations of wild-type SLT-1 and the mutants indicated were incubated with Vero cells for $6 \mathrm{~h}$ at $37^{\circ} \mathrm{C}$ and $\left[{ }^{35} S\right]$ methionine incorporation into cellular protein was subsequently determined. All values are the means of four replicate samples and are expressed as percentages of protein synthesis by untreated, control cells. $\boldsymbol{\Delta}$, SLT-1;, SLTP1; $\boldsymbol{\nabla}$, SLTP3; $\square$, SLTP4.

reduced toxicity in the absence of proteolytic cleavage (mutant SLTP4) is unclear, particularly as the catalytic activity of mutant SLTP4 seems to be very similar to that of wild-type SLT-1 (Fig. 2, compare lanes 10-12 with lanes 1-3).

\section{DISCUSSION}

In this study, we have investigated whether proteolytic processing of the catalytic A subunit of members of the Shiga toxin family, exemplified here by SLT- 1 from $E$. coli, is required for toxicity to mammalian cells. Previous work has clearly established that proteolytic processing of the $A$ subunit into $A_{1}$ and $A_{2}$ fragments does occur following toxin entry into mammalian cells (Garred et al., 1995b). Processing is achieved through the action of furin, which recognizes the sequence ArgX-X-Arg (Molloy et al., 1992), a sequence found within a disulphide loop in all members of the Shiga toxin family. Many bacterial toxins that modify target substrates catalytically in the cytosol of mammalian cells require proteolytic cleavage in order to act (Gordon \& Leppla, 1994). Some of these toxins, such as diphtheria toxin (Drazin et al., 1971) and Pseudomonas exotoxin A (Vasil et al., 1977), are synthesized as catalytically inactive, non-toxic proprotein precursors in which the catalytic and cell-binding subunits are present initially as part of a single polypeptide. When the inactive, native proforms of either diphtheria toxin or Pseudomonas exotoxin A enter mammalian cells, proteolytic cleavage releases the A fragment from the cell-binding $\mathrm{B}$ fragment and thereby activates these toxins. Once again, it is now clear that furin is the cellular endoprotease responsible for this activation. Both diphtheria toxin and Pseudomonas exotoxin A contain an Arg-X-X-Arg sequence within a disulphide loop and both are cleaved by furin in vitro (Chiron et al., 1994). Mutating the cleavage site so that it is no longer recognized by furin abolished cytotoxicity (Williams et al., 1990; Ogata et al., 1990). It has also been shown that cells lacking furin are resistant to both diphtheria toxin and Pseudomonas exotoxin A, but sensitivity can be restored by transfecting a cDNA encoding furin (Moehring et al., 1993; Tsuneoka et al., 1993).

Clearly, toxins in which the catalytic and cell-binding polypeptides are present initially in a single precursor require proteolytic processing by furin to release and thereby activate the catalytic A fragment. The Shiga toxins are somewhat different, however, in that the A subunit is not covalently attached to the cell-binding peptides of the B-subunit pentamer. Cells lacking furin remain sensitive to $S T$, although transfecting the furin gene increased both the rate of cleavage of endocytosed toxin and sensitivity to it (Garred et al., 1995a). Further, abolishing the furin cleavage site by mutation in the disulphide loops of ST (Garred et al., 1995b), SLT-1 (Burgess \& Roberts, 1993) and SLT-2 (Samuel \& Gordon, 1994) does not abolish cytotoxicity. However, proteolytic processing may still be essential and, if a second cleavage site remains available, this could account for the toxicity of the mutants analysed thus far. In the present study, it has been shown that eliminating the primary furin-recognition site of SLT-1 (mutant SLTP1) does not prevent intracellular cleavage (Fig. 3), confirming an earlier observation made in the case of ST (Garred et al., 1995b). On the basis of these data, mutant SLTP4 was produced, in which an additional putative furin cleavage site $\left(\mathrm{Arg}_{220}\right.$-Val-Gly-Arg $\left.2{ }_{223}\right)$ was mutated. It should be noted that the alternative processing site reported for ST by Garred et al. (1995b) lay within the disulphide loop, since reduction was required to release the $A_{1}$-sized fragment from the processed A subunit. Processing at this alternative site appeared to occur in the cytosol since, in contrast to the wild-type protein, it could be prevented by treating the cells with a membrane-permeable inhibitor of the cytosolic enzyme calpain (Garred et al., 1995b). It is possible that this ST mutant could have been cleaved at one of the Ala-Ser pairs, present in the disulphide loop, which had earlier been implicated as potential processing sites (Takao et al., 1988). In mutant SLTP3 produced in the present study, both Ala-Ser pairs as well as the primary furin site within the disulphide loop had been removed. This suggested that the processing observed for SLTP3 (Fig. 3 ) occurred at a site outside the disulphide loop, a contention supported by the finding that processing of mutant SLTP4 was abolished by an additional mutation introduced into the sequence outside the loop. Although mutant SLTP4 did not appear to be processed during cell entry (Figs 3 and 4) even when endocytosed toxin was incubated with cells for $6 \mathrm{~h}$, it did remain cytotoxic upon prolonged $(6 \mathrm{~h})$ incubation with cells, albeit $\sim 60$-fold less toxic than wild-type SLT-1 (Fig. 5). At present, it is 
not clear why some form of proteolytic processing is necessary for optimal cytotoxicity. It is possible that the uncleaved $A_{2}$ moiety reduces the efficiency of $A$ subunit membrane translocation into the cytosol, or somehow partially destabilizes it or enhances the rate of its intracellular degradation, effectively reducing the concentration of functional toxin in the cytosol. However, the most likely explanation for the need for processing for optimal activity comes from the X-ray crystallographic structure of ST (Fraser et al., 1994), which provides a clear structural basis for this requirement. In the uncleaved A subunit, residues 258-262 of $A_{2}$ lie adjacent to the active-site cleft of $A_{1}$ and the side chain of $\mathrm{Met}_{260}$ protrudes into the active site itself. This structural feature may explain why removal of the $A_{2}$ portion of ST/SLT, including residue 260 , results in increased catalytic activity. In conclusion, while it is clear that a form of SLT-1 that does not undergo any observable proteolytic cleavage during cell entry (mutant SLTP4) remains cytotoxic, cleavage at either the preferred furin site or an adjacent site is required for SLT-1 to exhibit maximal toxicity towards mammalian cells.

\section{REFERENCES}

Brown, J. E., Ussery, M. A., Leppla, S. H. \& Rothman, S. W. (1980). Inhibition of protein synthesis by Shiga toxin: activation of the toxin and inhibition of peptide elongation. FEBS Lett 117, 84-88.

Burgess, B. J. \& Roberts, L. M. (1993). Proteolytic cleavage at arginine residues within the hydrophilic disulphide loop of the Escherichia coli Shiga-like toxin I A subunit is not essential for cytotoxicity. Mol Microbiol 10, 171-179.

Calderwood, S. B., Auclair, F., Donohue-Rolfe, A., Keusch, G. T. \& Mekalanos, J. J. (1987). Nucleotide sequence of the Shiga-like toxin genes of Escherichia coli. Proc Natl Acad Sci USA 84, $4364-4368$.

Chiron, M. E., Fryling, C. M. \& FitzGerald, D. J. (1994). Cleavage of pseudomonas exotoxin and diphtheria toxin by a furin-like enzyme prepared from beef liver. J Biol Chem 269, 18167-18176.

Drazin, R., Kandel, J. \& Collier, R. J. (1971). Structure and activity of diphtheria toxin. II. Attack by trypsin at a specific site within the intact toxin molecule. J Biol Chem 246, 1504-1510.

Endo, Y., Tsurugi, K., Yutsudo, T., Takeda, Y., Ogasawara, T. \& Igarashi, K. (1988). Site of action of a Vero toxin (VT2) from Escherichia coli $\mathrm{O} 157: \mathrm{H} 7$ and of Shiga toxin on eukaryotic ribosomes. RNA $N$-glycosidase activity of the toxins. Eur $J$ Biochem 171, 45--50.

Fraser, M. E., Chernaia, M. M., Kozlov, Y. V. \& James, M. N. G. (1994). Crystal structure of the holotoxin from Shigella $d y s$ enteriae at $2.5 \AA$ resolution. Nat Struct Biol 1, 59-64.

Garred, O., van Deurs, B. \& Sandvig, K. (1995a). Furin-induced cleavage and activation of Shiga toxin. I Biol Chem 270, 10817-10821.

Garred, O., Dubinina, E., Holm, P. K., Olsnes, S., van Deurs, B., Kozlov, J. V. \& Sandvig, K. (1995b). Role of processing and intracellular transport for optimal toxicity of Shiga toxin and toxin mutants. Exp Cell Res 218, $39-49$.

Gordon, V. M. \& Leppla, S. H. (1994). Proteolytic activation of bacterial toxins: role of bacterial and host cell proteases. Infect lmmun 62, 333-340.
Kongmuang, U., Honda, T. \& Miwatani, T. (1988). Effect of nicking on Shiga-like toxin-I of enterohaemorrhagic Escherichia coli. FEMS Microbiol Lett 56, 105-108.

Laemmli, U. K. (1970). Cleavage of structural proteins during assembly of the head of bacteriophage T4. Nature 227, 680-685.

Lindberg, A. A., Brown, J. E., Stromberg, N., Westling-Ryd, M., Schultz, J. E. \& Karlsson, K.-A. (1987). Identification of the carbohydrate receptor for Shiga toxin produced by Shigella dysenteriae type 1. J Biol Chem 262, 1779-1785.

May, M. J., Hartley, M. R., Roberts, L. M., Krieg, P. A., Osborn, R. W. \& Lord, J. M. (1989). Ribosome inactivation by ricin A chain: a sensitive method to assess the activity of wild-type and mutant polypeptides. EMBO J 8, 301-308.

Moehring, J. M., Inocencio, N. M., Robertson, B. J. \& Moehring, T. J. (1993). Expression of mouse furin in a Chinese hamster cell resistant to Pseudomonas exotoxin A and viruses complements the genetic lesion. J Biol Chem 268, 2590-2594.

Molloy, S. S., Bresnahan, P. A., Leppla, S. H., Klimpel, K. R. \& Thomas, G. (1992). Human furin is a calcium-dependent serine endoprotease that recognizes the sequence Arg-X-X-Arg and efficiently cleaves anthrax toxin protective antigen. J Biol Chem 267, 16396-16402.

Muller, D., Vic, G., Critchley, P., Crout, D. H. G., Lea, N., Roberts, L. M. \& Lord, J. M. (1998). Chemical synthesis of globotriose and galabiose: relative stabilities of their complexes with Escherichia coli Shiga-like toxin-I as determined by denaturation-titration with guanidinium chloride. I Chem Soc Perkin Trans 1, 2287-2294.

Ogata, M., Chaudhary, V. K., Pastan, I. \& FitzGerald, D. J. (1990). Proccssing of Pseudomonas exotoxin by a cellular protease results in the gencration of a $37,000-\mathrm{Da}$ toxin fragment that is translocated to the cytosol. J Biol Chem 265, 20678-20685.

Olsnes, S., Reisbig, R. \& Eiklid, K. (1981). Subunit structure of Shigella toxin. J Biol Chem 256, 8732-8738.

Samuel, J. E. \& Gordon, V. M. (1994). Evidence that proteolytic separation of Shiga-like toxin type IIv A subunit into A1 and A2 subunits is not required for toxin activity. $J$ Biol Chem 269, 4853-4859.

Takao, T., Tanabe, T., Hong, Y.-M., Shimonishi, Y., Kurazono, H., Yutsudo, T., Sasakawa, C., Yoshikawa, M. \& Takeda, Y. (1988). Identity of the molecular structure of Shiga-like toxin I (VT1) from Escherichia coli $\mathrm{O} 157: \mathrm{H} 7$ with that of Shiga toxin. Microb Pathog 5, 357-369.

Tesh, V. L. \& O'Brien, A. D. (1991). The pathogenic mechanisms of Shiga toxin and the Shiga-like toxins. Mol Microbiol 5,

Tsuneoka, M., Nakayama, K., Hatsuzawa, K., Komada, M., Kitamura, N. \& Mekada, E. (1993). Evidence for involvement of furin in cleavage and activation of diphtheria toxin. $J$ Biol Chem 268, 26461-26465.

Immun 16, 353-361.

Williams, D. P., Wen, Z., Watson, R. S., Boyd, J., Strom, T. B. \& Murphy, J. R. (1990). Cellular processing of the interleukin-2 fusion toxin $\mathrm{DAB}_{486}$-IL-2 and efficient delivery of diphtheria fragment $\mathrm{A}$ to the cytosol of target cells requires $\mathrm{Arg}^{194}$. J Biol Chem 265, 20673-20677.

Received 6 November 1998; revised 8 January 1999; accepted 11 January 1999. 